\title{
Rare and Rare-Earth Metals in Coal Processing Waste
}

\author{
Tatiana Cherkasova ${ }^{1 *}$, Elizaveta Cherkasova $^{1}$, Anastasia Tikhomirova ${ }^{1}$, Alyona Bobrovni- \\ kova $^{1}$ and Irina Goryunova ${ }^{1}$ \\ ${ }^{1}$ T.F. Gorbachev Kuzbass State Technical University, 650000, 28 Vesennyaya St., Kemerovo, Russia
}

\begin{abstract}
An urgent issue for power plants operating on solid fuels (coal) is the issue of utilization or use of accumulated production waste - ash and slag materials - in the related production. Ash-slag materials are classified as "waste", usually grade 5; tens of millions of tons of them being produced annually in the Kemerovo region, which threatens the ecology of the region. At the same time, ash and slag is a very promising raw material. The use of this material as a base for the final product allows us to significantly expand the possibilities of using coal. The most widespread is the system of ash and slag involving in construction or as a replacement for sand in road construction, or as an additive to building mixtures. However, there are both industrially valuable and environmentally dangerous elements in ash-slag materials. Ash-slag materials can be considered as independent ore deposits located on the surface and requiring the costs of their extraction.
\end{abstract}

\section{Introduction}

Kuzbass is a coal region, where a large amount of ash-and-slag waste is produced during the operation of thermal power plants, which "dust", are washed out by atmospheric precipitation, polluting the environment [1-4].

The properties of thermal power plant ash and slag materials depend primarily on the characteristics of the mineral part of the source fuel and the methods of its combustion. In those years, when the boiler units of currently operating Kemerovo state district power station were designed, the main fuel was coal from the Kedrovsky mine and Butovskaya coal mine. It is for the burning of these coals that the equipment of the Kemerovo State District Power Plant and other power plants within the city of Kemerovo, where the boiler units with pulverized fuel combustion are installed, at which the temperature in the zone of active combustion exceeds the melting temperature of the ash, where designed, was projected.

In recent years, the list of coals supplied to thermal power plant from other open pits and deposits has expanded: burning of coals of "Zarechny", "Kotinskaya" and "Taldinskaya" mines began. It should be noted that these coals are close in their technological characteristics to the design ones.

\footnotetext{
* Corresponding author: ctg.htnv@,kuzstu.ru
} 
Ash-and-slag of thermal power plants are solid products of coal combustion formed in the furnace as a result of heat treatment of the initial mineral part of fuels, consisting mainly of rock-forming components, the remaining components are carbon, $\mathrm{CaSO}_{4}$ anhydrite, sometimes iron oxides and calcium aluminosilicates. The $85-95 \%$ of mineral part the fuel consists of clay minerals, mudstones, siltstones, i.e. of the same sedimentary rocks that make up the human habitat. The remaining $5-15 \%$ are mainly compounds of iron, calcium and trace elements.

For the years of power system operation, 10 million tons of ash and slag have been accumulated at the ash dump of the Kemerovo State District Power Plant. The total annual output of the ash-and-slag materials is about 175 thousand tons.

The composition of slag includes small amounts of rare and rare-earth elements (REE), for the extraction of which highly selective technologies are required, and the extraction of the REE complex, rare and noble metals increases the profitability of coal processing waste [4-15].

And-slag materials are rare and rare-earth elements.

The consumption of REE is growing quite rapidly, since modern high-tech devices and installations, from a mobile phone to a nuclear reactor, cannot exist without them. Currently REE is supplied to the whole world by China, but now these supplies are reoriented to the interior of the country. Thirty years ago, Russia took the third place in production and second place in the reserves of REE, fully meeting the needs of the domestic market, supplying, in addition, products for export. At present, all the needs of Russia are met through imports, that is, Russia is on the "rare earth addict" [12]. There is only one way out: to revive the extraction and production of REE; all the more so as the reserves in the Russian Federation are $30 \%$ of the world's, in addition, the ash of natural coal is a source of raw materials for rare earth elements and rare elements.

\section{Materials and methods}

The objects of research were slag and fly ash from the Kemerovo SDPS.

The preliminary magnetic separation of objects was carried out. It was found that the share of the magnetic fraction in the fly ash is about $5 \%$, the slag was not subjected to separation (there was no magnetization). The lots of slags were crushed to $0.2 \mathrm{~mm}$ in size. Analyzes for the content of chemical components were carried out by the method of optoelectronic spectroscopy with inductively coupled plasma on the spectrometer iCAP 6500DIO and consisted of the following stages:

1) preparation for solid sampling;

2) extraction by royal vodka;

3) analysis of compacts;

4) analysis of the extract.

The leaching of the samples was carried out by solutions of mineral acids and alkalis. To win and separate the components, the ion flotation method was used, which is applicable for the extraction of substances from very low concentration solutions, including REE $[20,21]$. Flotation machine parameters, flotation time, gas or air flow rate are very important for ion flotation, collectors [15] should be selected. The efficiency of the flotation REE winning in a foam product is determined by the $\mathrm{pH}$ of the medium, the consumption of the collector and the concentration of REE in the solution.

To carry out experiments on the extraction of rare metals and REE, anionic superficially active substance - surfactant sodium dodecyl sulfate $\mathrm{C}_{12} \mathrm{H}_{25} \mathrm{SO}_{4} \mathrm{Na}$, which is the sodium salt of lauryl sulfuric acid, was used. This non-toxic and inexpensive reagent has both blowing agent and collector properties. 


\section{Results and discussion}

The magnetic fraction of ash contains mainly iron. The non-magnetic fraction contains $\mathrm{SiO}_{2}, \mathrm{Al}_{2} \mathrm{O}_{3}, \mathrm{CaO}, \mathrm{MgO}$ oxides, which are of commercial interest for the use in building materials. REE and rare elements are distributed between two fractions.

Analytical results on the content of rare elements and REE are presented in Table. 1-3.

Table 1 The content of rare and rare-earth elements in fly ash of Kemerovo State District Power Plant

\begin{tabular}{|c|c|c|}
\hline \multirow{2}{*}{ Elements } & \multicolumn{2}{|c|}{ Content } \\
\cline { 2 - 3 } & $\%$ & $\mathrm{~g} / \mathrm{t}$ \\
\hline $\mathrm{Sr}$ & $1.1 \cdot 10^{-2}$ & 110.00 \\
\hline $\mathrm{Zr}$ & $2.3 \cdot 10^{-4}$ & 2.30 \\
\hline $\mathrm{Nb}$ & $7.0 \cdot 10^{-4}$ & 7.00 \\
\hline $\mathrm{Ga}$ & $9.0 \cdot 10^{-4}$ & 9.00 \\
\hline $\mathrm{Mo}$ & $8.7 \cdot 10^{-4}$ & 8.70 \\
\hline $\mathrm{Au}$ & $1.2 \cdot 10^{-4}$ & 1.20 \\
\hline $\mathrm{Ag}$ & - & - \\
\hline $\mathrm{V}$ & $5.3 \cdot 10^{-3}$ & 53.00 \\
\hline $\mathrm{P} 3:$ & $1.4 \cdot 10^{-3}$ & 14.00 \\
\hline $\mathrm{Y}$ & $6.8 \cdot 10^{-5}$ & 0.68 \\
\hline $\mathrm{Eu}$ & $1.9 \cdot 10^{-3}$ & 19.00 \\
\hline $\mathrm{La}$ & $7.0 \cdot 10^{-4}$ & 7.00 \\
\hline $\mathrm{Pr}$ & $1.5 \cdot 10^{-4}$ & 15.00 \\
\hline
\end{tabular}

Table 2 The content of rare and rare-earth elements in the slag of Kemerovo State District Power Plant

\begin{tabular}{|c|c|c|}
\hline \multirow{2}{*}{ Elements } & \multicolumn{2}{|c|}{ Content } \\
\cline { 2 - 3 } & $\%$ & $\mathrm{~g} / \mathrm{t}$ \\
\hline $\mathrm{Sr}$ & $1.9 \cdot 10^{-2}$ & 190.00 \\
\hline $\mathrm{Zr}$ & $4.7 \cdot 10^{-3}$ & 47.00 \\
\hline $\mathrm{Nb}$ & $8 \cdot 10^{-5}$ & 0.80 \\
\hline $\mathrm{Ga}$ & $1 \cdot 10^{-4}$ & 1.00 \\
\hline $\mathrm{Mo}$ & - & - \\
\hline $\mathrm{Au}$ & - & 0.10 \\
\hline $\mathrm{Ag}$ & $1 \cdot 10^{-5}$ & 6.60 \\
\hline $\mathrm{V}$ & $6.6 \cdot 10^{-4}$ & 3.00 \\
\hline $\mathrm{P} 3:$ & $3 \cdot 10^{-4}$ & 0.15 \\
\hline $\mathrm{Y}$ & $1.5 \cdot 10^{-5}$ & 4.70 \\
\hline $\mathrm{Eu}$ & $4.7 \cdot 10^{-4}$ & 1.70 \\
\hline $\mathrm{La}$ & $1.7 \cdot 10^{-4}$ & 1.10 \\
\hline $\mathrm{Pr}$ & $1.1 \cdot 10^{-4}$ & \\
\hline $\mathrm{Sm}$ & & \\
\hline
\end{tabular}

Table 3 The content of rare and rare-earth elements in concentrates

\begin{tabular}{|c|c|c|}
\hline Elements & $\begin{array}{c}\text { Concentrate 1 content, } \\
\mathbf{\%} / \mathbf{g} / \mathbf{t}\end{array}$ & $\begin{array}{c}\text { Concentrate 2 content, } \\
\mathbf{\%} / \mathbf{g} / \mathbf{t}\end{array}$ \\
\hline $\mathrm{Sr}$ & $2,7 \cdot 10^{-1} / 2700$ & $1,3 \cdot 10^{-1} / 1300$ \\
\hline $\mathrm{Zr}$ & $1 \cdot 10^{-1} / 100$ & $1,2 \cdot 10^{-1} / 1200$ \\
\hline $\mathrm{Nb}$ & $9 \cdot 10^{-3} / 90$ & $8,5 \cdot 10^{-3} / 85$ \\
\hline $\mathrm{Ga}$ & $5 \cdot 10^{-3} / 50$ & $4,8 \cdot 10^{-3} / 48$ \\
\hline $\mathrm{Mo}$ & $3 \cdot 10^{-2} / 300$ & $2 \cdot 10^{-2} / 200$ \\
\hline
\end{tabular}




\begin{tabular}{|c|c|c|}
\hline V & $2 \cdot 10^{-1} / 2000$ & $3 \cdot 10^{-1} / 3000$ \\
\hline$\Sigma$ P3Э & $8,5 \cdot 10^{-2} / 850$ & $7,7 \cdot 10^{-2} / 770$ \\
\hline
\end{tabular}

The resulting concentrates are suitable for further processing.

\section{Conclusions}

In Russia over the past 40 years, more than 300 technologies for the use of ash and slag materials in more than 20 areas have been developed. Nevertheless, today we are here at one of the last places in the world. The main reason until recently there was no any state policy in the field of ash and slag waste utilization - in the country and until now there are no regulatory legal acts regulating their use. As a matter of principle, energy companies themselves could be involved in ash and slag waste processing, but when there is no state policy and in the conditions of restricting tariff growth, it is very difficult for them to justify investments in such projects.

The problem of ash and slag is particularly relevant for Siberia. 44 percent of all domestic thermal power engineering is concentrated here, the overwhelming majority of which are coal stations.

The recovered value of rare earth elements and rare metals, as well as the huge need of high-tech industries in them and environmental improvement of the region necessitate the implementation of works concerning the deep processing of ash and slag waste.

\section{References}

1. B.F. Nifantov, V.P. Potapov, N.V. Mitina, Processing prospects, 104 (2003)

2. V.V. Krapivintseva, Pacific Geology, 24:1, 73 (2005)

3. M.D. Skurskiy, Forecast of rare earth - rare metal - oil-and-gas fields in Kuzbass, (Kuzbass University Puiblishing, 2005)

4. A. A. Cherepanov, V.T. Kardash, Geology and minerals of the World Ocean, 2, 98 (2009)

5. V.A. Salikhov, Bulletin of Tomsk State University. Economy, 1:25, 123 (2014)

6. M. I. Gamov, N.V. Granovskaya, S.V. Levchenko, Metals in coals, 45 (Rostov-onDon : YuFU., 2012.)

7. S.I. Arbuzov, V.V. Yershov, A. A. Potseluev, L. P. Rikhvanov, Rare elements in Kuznetsk basin coals, 248 (Kemerovo Printing and Publishing Complex, 1999)

8. S.I. Arbuzov, Geochemistry of rare elements in Central Siberia coals: thesis for a Doctor's of Science degree in Geology and Mineralogy, 499 (Tomsk, 2005)

9. S. I. Polkin, Processing of ores and placers of rare and precious metals, 428 (Moscow: Nedra, 1987)

10. V. A. Salikhov, Bulletin of KuzSTU, 4, 255 (2011)

11. S. I. Arbuzov, , Bulletin of TPU, 311:1, 77 (2007)

12. K. Shunsuke, K. Yuichi, K. Hiroshi, W. Kazuaki, Open Journal of Physical Chemistry 3, 69 (2013)

13. F. Wojciech, M. Małgorzata M. Wiatros-Motyka, M. Wdowin, Environmental Science and Pollution Research, 22, 9464 (2015)

14. X. Tran, W. Ping, M. Dustin, Elsevier. ScienceDirect, 163, 129 (2016) 
15. N. Lange, I. Camargo, A. Figueiredo, L.Castro, M. Vasconcellos, R. Ticianelli, Journal of Radioanalytical and Nuclear Chemistry, 311, 1235 (2017)

16. P. Orlov, Rare earth addiction (The Russian Atomic Community, 2005)

17. P.A. Vlasov, DonNTU, 6:125, 152 (2007)

18. G.L. Pashkov, S.V. Saikova, V.I. Kuzmin, M.V. Panteleeva, A.N. Kokorina, E.V. Linok, Journal of Siberian Federal University. Engineering \& Technologies, 5:5 ,520 (2012)

19. O.V. Afanasieva, G.R. Mingaleeva, E.V. Shamsutdinov, S.Yu. Gorbunov, Tatarstan power engineering, 3:39, 41 (2015)

20. O.V. Afanasieva, G.R. Mingaleeva, A.D. Dobronravov, E.V. Shamsutdinov, Bulletin of higher education institutions. Issues of Power Engineering, 7:8, 26 (2015)

21. N.V. Fedorova, D.A. Shafrost, Heat power engineering, 1, 53 (2015)

22. L.N. Adeeva, V.F. Borbat, Bulletin of Omsk University, 2, 141 (2009)

23. B.S. Ksenofontov, A.S. Kozodaev, R.A. Taranov, M.S. Vinogradov, I. A. Butorova, E.V. Senik, A. A. Voropaeva, Engineering Bulletin, 11, 121 (2014)

24. Yu. A. Vershakova, Extraction of rare-earth elements by the method of ion flotation in the case of nitric acid processing of apatite: thesis for a Csandidate's of Technical Science degree, 180 (Apatites, 2003)

25. D. V. Abryutin, K.A. Streltsov, Bulletin of higher education institutions. Ferrous Metallurgy, 3, 3(2013)

26. O. A. Lobacheva, N. V.Dzhevaga, National Mineral and Raw University. Mining, 106 (2016) 
